\title{
Case study: The Transnationalization of Russian Oil and Gas Companies
}

\author{
S. Lavrov, A. Aleksanyan ${ }^{1}$
}

Sergey Lavrov - PhD in economic science, professor, National Research University Higher School of Economics; main research fellow, Russian Presidential Academy of National Economy and Public Administration; 17-1 Malaya Ordynka Street, Office 407-408, 119017 Moscow, Russian Federation; E-mail: lavrovsn@mail.ru

Anna Aleksanyan - Post-graduate student, National Research University Higher School of Economics; 17-1 Malaya Ordynka Street, Office 407-408, 119017 Moscow, Russian Federation; E-mail: a.a.aleksanyan@mail.ru

The value of multinational enterprises (MNEs) as the main players in the global economy is constantly increasing. More and more companies from developing and transition economies are starting to do business beyond their national borders. Not all of them strictly belong to the category of MNEs, as is the case for Russia's largest companies.

This article analyzes the international activities of Russian MNEs. The authors study the place of MNEs in the modern world and examine the transformation of the concept of an MNE in the international practice. They identify the internationally accepted criteria that classify a company as an MNE. They analyze the international activities of the largest Russian companies in the oil and gas sector (Gazprom, Rosneft, Lukoil, Surgutneftegas, Novatek) and their possible classification as MNEs. The article also assesses the influence of the economic and political sanctions on the international activities of Russian $M N E$ in the oil and gas sector.

The methodological basis for the study is the dialectical method of investigating phenomena and processes in the modern world as the most effective way to achieve goals. The authors pay particular attention to the practical application of comparative economic analysis, classification and empirical generalization of original data.

The authors came to seven conclusions. First, there is no single approach to defining the essence of MNEs. Second, the indicators that classify a company as an MNE can be divided into qualitative and quantitative criteria. Third, not all the large companies in Russia engaged in expanding into foreign markets can be classified as MNEs by the formal criteria. Fourth, most Russian MNEs have an unstable position in international ratings of MNEs, with the exception of Lukoil. Fifth, the main problems of Russian MNEs include the inefficiency of foreign assets, the lack of experience in managing international holdings and the longstanding crisis of the Russian economy. Sixth, political and economic sanctions severely restrict the business relationship between Russian companies (particularly oil and gas companies) and key international partners, which leads to decreased investment, disrupted implementation of many major projects plans and the decline of companies' financial performance. Seventh, the current situation should spur Russian companies to adapt their economic policies to the new economic realities, to restore full technological and financial chains via expanding business relationships with companies in developing countries, using private sector resources and government support.

${ }_{1}$ The editorial board received the article in November 2016. 
Key words: oil and gas sector; United Nations; United Nations Conference on Trade and Development; transnationalization; transnationality index (TNI); Gazprom; Lukoil; Novatek; Rosneft; Russian companies; sanctions; Surgutneftegaz; multinational enterprises (MNEs)

For citation: Lavrov S., Aleksanyan A. (2017) Case study: The Transnationalization of Russian Oil and Gas Companies. International Organisations Research Journal, vol. 12, no 1, pp. 209-228 (in Russian and English). DOI:10.17323/1996-7845-2017-01-209. 
The current global role of multinational enterprises (MNEs) cannot be overestimated. In a globalized economy with conditional opening of markets and increasing competition, the largest national companies are forced to do business across borders in order to increase their competitiveness and improve business performance.

According to UNCTAD, there are more than 100,000 parent multinationals controlling more than 890,000 subsidiaries and affiliated companies abroad. These companies employ about 75 million people.

MNEs account for more than $50 \%$ of global industrial production. They make up more than $60 \%$ of world trade ( $\$ 36.4$ trillion) and over $90 \%$ of foreign direct investment (FDI) in foreign countries ( $\$ 25.9$ trillion).

MNEs are key holders of industrial and intellectual property in the modern world. Their share accounts for about $85 \%$ of the global database of patents and licenses for new equipment, technology and know-how.

The volume of mergers and acquisitions (M\&A) realized by MNEs reached almost $\$ 400$ billion in 2015, and market capitalization of some MNEs exceeded $\$ 500$ billion, while annual sales reached \$150-200 billion [UNCTAD, 2015, p. 18, p. 146].

Many writers believe that in some cases MNEs have a much more powerful impact on the economy and politics than state structures do. Gribova S. N., in her work about the problems of the regionalization and globalization of the world economy, shows that the role of the nation state is gradually being reduced with the expansion of the spheres of MNEs' influence, and an adjustable international industrial and financial complex is arising, based on the global division of labor and macroeconomic features of the regions [Gribova, 2005].

According to Pozdnjakov A. I., there is an unprecedented growth of financial and economic power and political influence of multinational corporations and banks. For example, US presidential elections in recent decades have been contests between New York MNBs (Democrats) and oil MNEs (Republicans) [Pozdnjakov, 2011].

There is an opinion that the activities of MNEs as a leading form of concentration of capital, their competition with each other, and a variety of competitive strategies (such as transnational mergers, acquisitions, etc.), are a powerful driver of change in the global geo-economic situation: modern MNEs are no longer guided by the interests of a particular country, even if it is a parent country. Their only priority is their own interests. Most MNE activities are outside the control zone of the country, and consequently the influence over the corporation by a particular country is decreasing [Nikitina, 2009].

Questions about changing the role of MNEs in global economic processes, and their impact on the development of world politics, have been repeatedly raised at the UN, which led eventually to the development and creation of the document entitled Code of Conduct of MNEs. However, since long before the publication, experts from international organizations have tried to identify the concept of business transnationalization and reference to the category of MNEs of various companies and corporations.

The concept of the MNE has been undergoing major transformations in modern scientific and applied literature, and requires some conceptual ordering. It is especially important to unify the criteria of reference of these or those corporations as being transnational, in that they act as the largest Russian holdings on international markets and 
create networks of affiliated structures abroad. In fact, today a certain, not very large, group of Russian companies fully aspires to the status of MNEs. But more on that later on.

The pioneer in the use of the MNE concept was the United Nations (UN), which in 1974 introduced the term in the process of developing the Code of Conduct of MNEs.

Its exact wording, taking into account the text and editorial features of international legal documents, is: "an enterprise, comprising entities in two or more countries, regardless of the legal form and fields of activity of these entities, which operates under a system of decision-making, permitting coherent policies and a common strategy through one or more decision-making centres, in which the entities are so linked, by ownership or otherwise, that one or more of them may be able to exercise a significant influence over the activities of others, and, in particular, to share knowledge, resources and responsibilities with the others" [UNCTAD, 2016].

After 12 years, in 1986, this determination was slightly transformed and the MNE in the new edition of the Code came to mean an enterprise of public, private or mixed ownership, comprising entities in two or more countries, regardless of the legal form and fields of activity of these entities, operating under a system of decision-making, and permitting coherent policies and a common strategy through one or more decision-making centres, in which the entities are so linked, by ownership or otherwise, that one or more of them may be able to exercise a significant influence over the activities of the others, and, in particular, to share knowledge, resources and responsibilities with the others [UNCTAD, 2016].

As you can see, the MNE definition has not undergone significant changes over the analyzed period. Only separate concepts and formulations have been specified. It took a little more than 20 years on the development of the now generally accepted definition of the MNE, which was formulated by UNCTAD in 2008 and is now used in official documents. "MNEs are a venture established in any organizational-legal form and consisting of parent and controlled by foreign (subsidiary) companies located, respectively, in the home and host countries and territories. The parent company of the affiliated entities of the transnational corporations, should be no less than $10 \%$ of the voting shares of the parent companies or similar shares in the authorized capital for non-corporate forms of ownership" [UNCTAD, 2016]. ${ }^{2}$

The above definitions give many reasons for a highly subjective evaluation of the processes occurring in the world economy and the classification of certain companies in the MNE category, as they contain almost no quantitative characteristics of reference companies to the researched category.

${ }^{2}$ This formulation probably formed base also for experts of Organization for Economic Cooperation and Development (OECD) who during preparation of "OECD Guidelines for multinational enterprises" in 2011 used the following determination of MNE: "These enterprises operate in all sectors of the economy. They usually comprise companies or other entities established in more than one country and so linked that they may co- ordinate their operations in various ways. While one or more of these entities may be able to exercise a significant influence over the activities of others, their degree of autonomy within the enterprise may vary widely from one multinational enterprise to another. Ownership may be private, State or mixed." [OECD, 2011, p. 17]. 
All of this has given rise to a wide variety of definitions of an MNE occurring in Russian and foreign publications devoted to this subject. Here are just some of them.

The American scientists Walters R. and Blake J. believe that MNEs are economic enterprises which have headquarters in one country and organize a business in one or more foreign countries [Panibratov, 2006].

The same view is shared by Hill $\mathrm{Ch}$. In his classic work "International Business" he briefly and clearly defines the transnational enterprise as "a business entity performing production activities in two or more countries" [Hill, 2013, p. 45].

A similar definition is also given by Caves R., who considers an MNE to be an enterprise that controls and manages production establishments (plants) located in at least two countries [Caves, 2007, p. 1].

In Russian scientific literature there is also quite a large variety of definitions of MNEs. Here are some of them.

Smitienko B.M. defined a MNE as a holding company that uses in its activities an international approach, which involves the formation of a transnational industrial, commercial and financial complex with a single decision-making center in the home country, and with branches in other countries [Smitienko, 2009, p. 19-26].

According to Belyaev I.Y. and Plotitsyna L.A., the process of a transnationalization company implies the transfer of reproduction processes from one country to another (or others) through foreign direct investment, which in contrast to the portfolio, includes investments made abroad in order to organize branches or establish control over foreign companies, which become dependent [Jeskindarov et al., 2010].

The list of definitions can be continued. However it is clear that there is no common approach to defining the essence of MNEs. There are many factors to it. One of them is that the effects of MNEs activities on the global and regional scales are mixed, and the reasons for their formation and development are very diverse.

Nevertheless, in our opinion it is still possible to identify the actual signs that categorise a company as an MNE. These focus on (a) general features of all enterprises that lead transnational economic activities, and (b) on quantifying and expert evaluation. They can be divided into two categories. The first is quantitative (summarizing the opinions of the authors, who are presented in a variety of sources):

(1) The number of foreign countries in which the corporation operates should be at least two;

(2) the number of countries in which the corporation has production capacity should not be less than three;

(3) the turnover and market capitalization of the company should be more than $\$ 1$ billion;

(4) the share of foreign operations in income or corporate sales should be not less than $25 \%$;

(5) possession of the parent company should be at least $10 \%$ of the voting shares or share capital of subsidiaries;

(6) the top management of the company should have representatives from at least two countries; 
(7) the transnationality index is usually not less than $25 \%$.

The second category is qualitative:

(A) leading positions in key markets;

(B) a single decision-making system;

(C) a vertically integrated structure of ownership and asset management;

and possibly some other characteristics.

By following these criteria it is possible to assign a certain company to the category of transnational.

US multinationals currently play a leading role in global processes, with the nature and scope of trade and investment expansion exceeding industrial and financial companies of other countries. However, the influence of American multinational corporations is gradually becoming leveled and balanced on world markets by the sustainable leading positions of MNEs of Western Europe and Japan, as well as the emergence and active conquest of transnational corporations in developing countries (China, Russia, India, South Korea, Brazil, Mexico and others).

The process of transnationalization of business has also affected Russian corporations, which in the late 90's actively mastered the tools of capital exports and expansion in the global commodity markets.

Among the leaders of Russian oil and gas companies by capitalization are Gazprom, Rosneft, Lukoil, Surgutneftegas, and Novatek (Table 1).

Table 1: The largest Russian oil and gas companies

\begin{tabular}{|l|c|c|c|}
\hline \multicolumn{1}{|c|}{ Companies } & $\begin{array}{c}\text { Market capitalization, } \\
\text { billion dollars }\end{array}$ & $\begin{array}{c}\text { Place in ranking of largest } \\
\text { companies in developing } \\
\text { countries }\end{array}$ & $\begin{array}{c}\text { Place in global } \\
\text { rating }\end{array}$ \\
\hline Gazprom & 56.57 & 18 & 170 \\
\hline Rosneft & 45.97 & 25 & 213 \\
\hline LUKOIL & 39.58 & 38 & 441 \\
\hline Surgutneftegaz & 27.47 & 67 & - \\
\hline Novatek & 22.57 & 91 & \\
\hline
\end{tabular}

Source: Financial Time, 2015.

These companies are among the 100 largest in developing countries by capitalization, and they are included in the global top 500 ranking (with the exception of Novatek). Shares in these companies are among the blue chips on the Russian stock market. Their total share in Russia's GDP is $2.1 \%$, amounting to 15.2 trillion rubles (GDP of Russia in 2015 was 71 trillion rubles, revenue of Gazprom was 5.5 trillion rubles, Rosneft -3.7 trillion rubles, LUKOIL - 4.7 trillion rubles, Surgutneftegaz - 0.9 trillion rubles, Novatek -0.4 trillion rubles) [RBC, 2015]. According to the above figures, this group of companies can be 


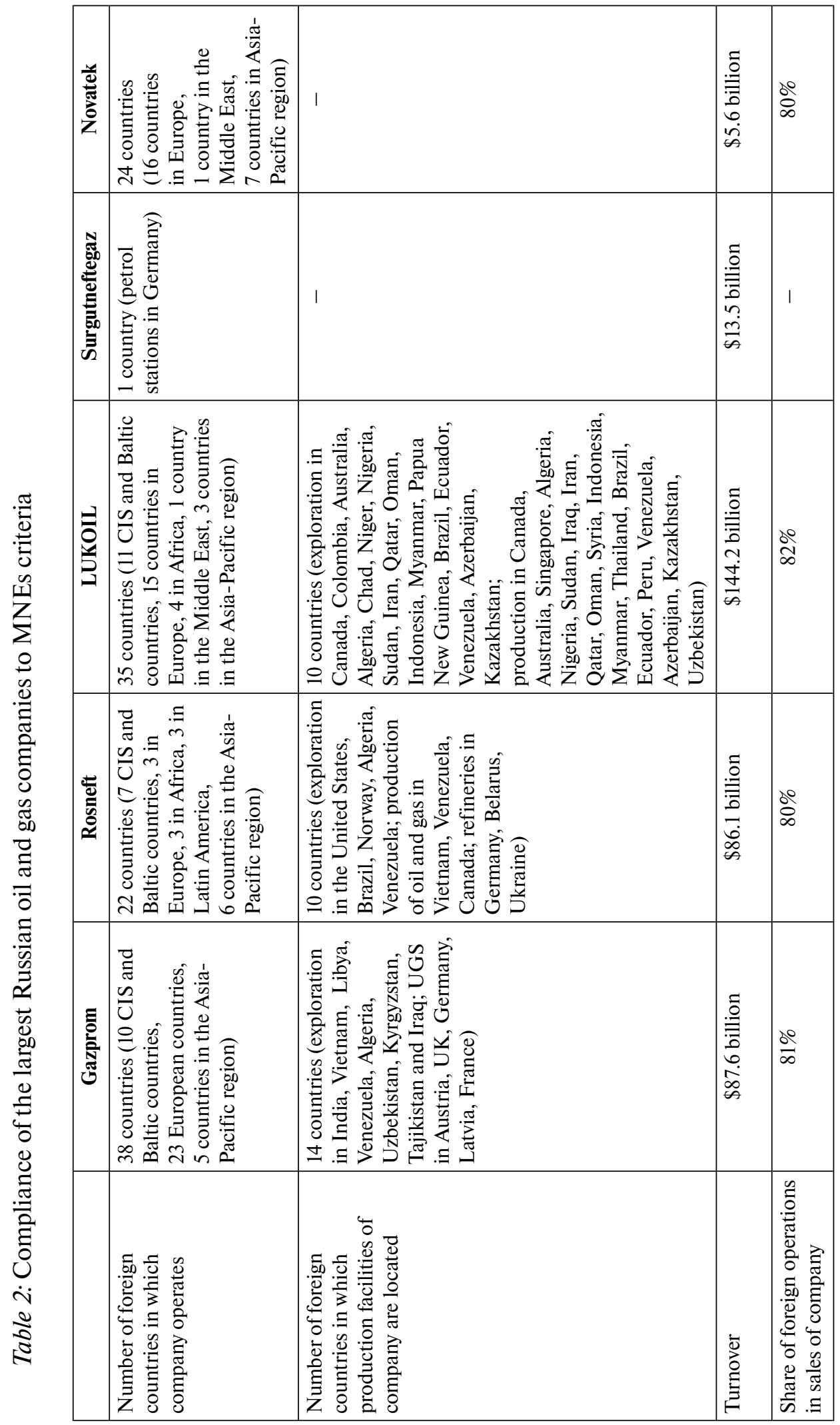




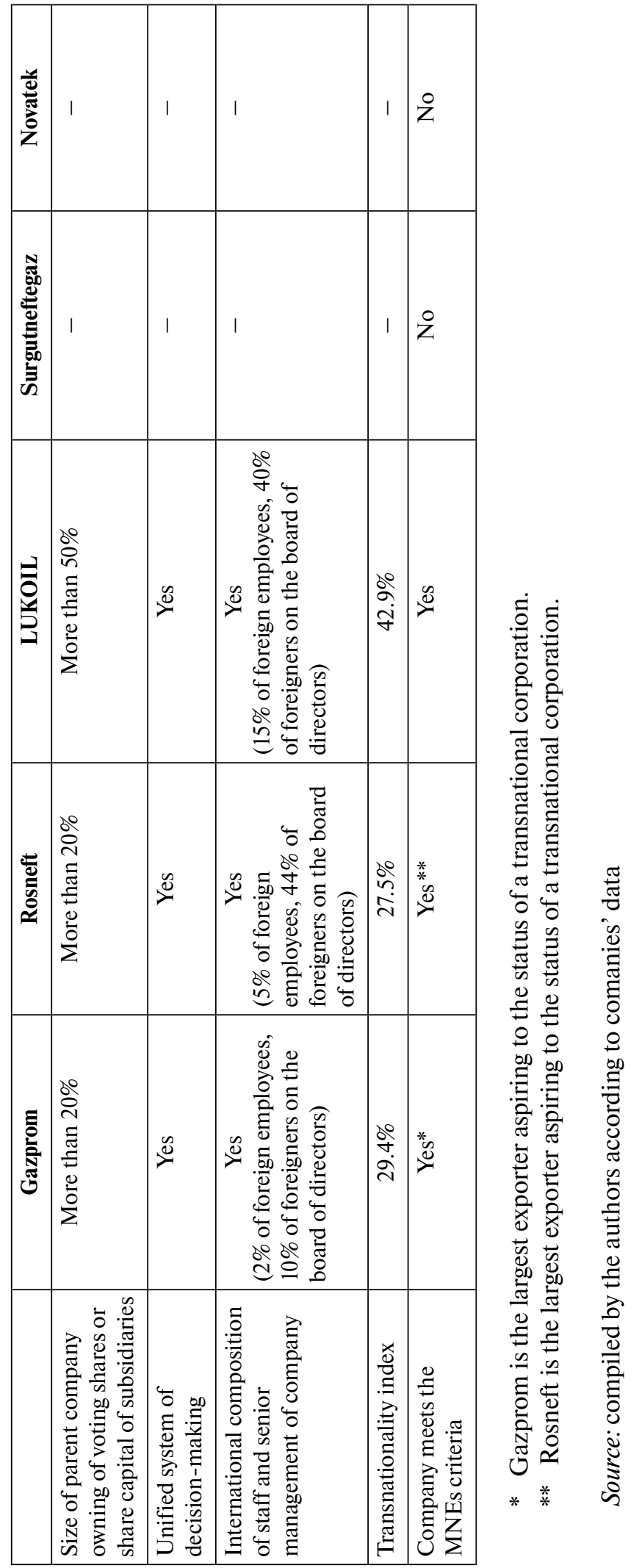


considered leaders of Russian business. But a question arisis: are Russia's largest companies included in the global world markets and are they multinationals in the literal sense of the term? Or do they belong to the category of the largest national companies, which play a significant role in the Russian market and have a strong influence on the economy and the dynamics of its development, but which perform only their first steps in the global economy and have little impact on the distribution of forces in the business world? Let's try to analyze the situation and answer to these questions, using the quantitative and qualitative criteria stated above.

The industry leader - Gazprom - is a global energy company focused on geological exploration, production, transportation, storage, processing and sales of gas, gas condensate and oil, sales of gas as a vehicle fuel, as well as generation and marketing of heat and electric power. In terms of capitalization it is in first place among Russian oil and gas companies ( $\$ 56.57$ billion). The company meets the quantitative and qualitative criteria of reference to the category of MNEs. But the transnationality index of the company is at a very low level, since a key indicator of the international expansion of the company is the size of foreign sales (the size of foreign sales is $81 \%$ of total sales, while the size of foreign assets barely exceed $5 \%$ and the number of employees abroad is only $2 \%$ ).

These figures show that the total share of foreign assets and employees working abroad is very low. The critical level of $25 \%$ in the transnationality index is exceeded primarily due to the export of mainly domestic goods which is not a criterion for transnationalization. This only confirms the export-oriented nature of its activities. It gives reason for the authors to conclude that Gazprom is the leader of the Russian oil and gas sector, which currently only reaches the status of transnational corporations in the classical sense of the term.

Rosneft is the leader of Russia's petroleum industry and the world's largest publicly traded petroleum company. The company's main activities include prospecting and exploration of hydrocarbon deposits, oil, gas and gas-condensate production, upstream offshore projects, processing, as well as oil, gas, and petrochemical marketing in Russia and abroad. The company's capitalization is $\$ 45.97$ billion.

The production and sales model of the company is similar to that of Gazprom (Table 2). The transnationality index of Rosneft exceeds $25 \%$ but its structure and basic level are formed mainly from export sales. Sales abroad amount to $80 \%$ (total sales were $\$ 83.9$ billion, sales abroad were $\$ 67$ billion), and foreign assets and the number of personnel abroad make up only $1.1 \%$ (total assets: $\$ 104.9$ billion, assets abroad: $\$ 1.1$ billion) and $1.8 \%$ (employees: 168,000, employees abroad: about 3,000), respectively.

In third place by capitalization in our list is LUKOIL. It is the largest vertically private integrated oil and gas company in the Russian fuel and energy complex. The company's primary activities are the exploration, production and refining of oil and natural gas, oil and petrochemicals. The company acts both in Russia and abroad. LUKOIL is the first Russian company to be included in international ratings of the world's largest MNEs. Today the company ranks 11th among the largest MNEs in developing countries by foreign assets and 67 th on the transnationality index $(42.9 \%)$.

Surgutneftegaz is one of the largest companies in the Russian oil and gas industry (capitalization: $\$ 27.47$ billion). The company's main businesses are exploration and 
production of hydrocarbons; processing of oil, gas and electricity; production and sales of petroleum products, gas products; and production of petroleum products and gas products. In contrast to the three companies considered above, Surgutneftegaz is a Russian national (internal) company (table 2). Oil and gas production and oil refining enterprises are located within the country, as well as the market. The company acts only within its own country. The exception is a network of gas stations in Germany. This is its first attempt to act on international markets. However, the company is not an MNE and does not aspire to this status.

The last Russian corporation on our list is Novatek. This company is the largest Russian independent producer of natural gas (market capitalization: $\$ 22.57$ billion). Its main activities include exploration, production, refining and sales of natural gas and liquid hydrocarbons. It has 20 years of experience in the Russian oil and gas industry. All production activities of the company (exploration, production and processing of raw materials) are carried out within Russia. At the same time the company is export-oriented. Novatek sells its products in 24 countries, which makes it a net exporter rather than an MNE (Table 2).

The analysis showed that not all of the largest companies in Russia acting on foreign markets are MNEs. Domestic companies have started to move to transnationalization and integration in global markets relatively recently, and these processes occur with varying success. There are a lot of objective and subjective reasons for this. This trend is true not only in the company's key raw materials for the Russian oil and gas sector. And the tendency belongs not only to oil and gas companies.

Let's look at the general process of transnationalization of Russian companies in all segments of the Russian market.

Table 3. Leading Russian corporations in the ranking of the top 100 non-financial MNEs from developing and transition economies, ranked by foreign assets (Billions of dollars and thousands of employees)

2008

\begin{tabular}{|c|c|c|c|c|c|c|c|c|c|c|}
\hline \multicolumn{2}{|c|}{ Ranking by: } & \multirow[t]{2}{*}{ Corporation } & \multirow[t]{2}{*}{ Industry } & \multicolumn{2}{|c|}{ Assets } & \multicolumn{2}{|c|}{ Sales } & \multicolumn{2}{|c|}{ Employment } & \multirow[t]{2}{*}{ TNI\% } \\
\hline 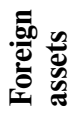 & $\bar{Z}$ & & & & 氶 & 占 & 窇 & 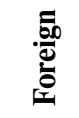 & हैँ & \\
\hline 8 & 61 & LUKOIL & $\begin{array}{l}\text { Petroleum } \\
\text { Refining } \\
\text { and Related } \\
\text { Industries }\end{array}$ & 21.5 & 71.5 & 87.6 & 107.7 & 23. & 152.5 & 42.2 \\
\hline 23 & 53 & Evraz & $\begin{array}{l}\text { Metal } \\
\text { and metal } \\
\text { products }\end{array}$ & 11.2 & 19.4 & 12.8 & 20.4 & 29.5 & 134 & 47.5 \\
\hline 32 & 77 & Severstal & $\begin{array}{l}\text { Metal } \\
\text { and metal } \\
\text { products }\end{array}$ & 8.1 & 22.5 & 9.3 & 22.4 & 12.7 & 96.7 & 30.2 \\
\hline
\end{tabular}




\begin{tabular}{|c|c|l|l|c|c|c|c|c|c|c|}
\hline 50 & 89 & System & $\begin{array}{l}\text { Telecom- } \\
\text { munications }\end{array}$ & 5.7 & 29.2 & 4 & 16.7 & 11 & 80 & 19.1 \\
\hline 64 & 93 & $\begin{array}{l}\text { Norilsk } \\
\text { Nickel }\end{array}$ & $\begin{array}{l}\text { Metal } \\
\text { and metal } \\
\text { products }\end{array}$ & 4.4 & 20.8 & 2 & 14 & 4 & 88.1 & 13.3 \\
\hline 74 & 83 & VimpelCom & $\begin{array}{l}\text { Telecom- } \\
\text { munications }\end{array}$ & 3.7 & 15.7 & 1.5 & 10.1 & 10.2 & 38.4 & 21.8 \\
\hline 81 & 92 & Mechel & $\begin{array}{l}\text { Metal } \\
\text { and metal } \\
\text { products }\end{array}$ & 2.9 & 12 & 1.4 & 10 & 8.2 & 83.7 & 16.0 \\
\hline 94 & 81 & TMK & $\begin{array}{l}\text { Metal } \\
\text { and metal } \\
\text { products }\end{array}$ & 2.4 & 7.1 & 2.3 & 5.7 & 4.1 & 48.5 & 27.4 \\
\hline
\end{tabular}

Source: UNCTAD, World Investment Report 2010.

2010

\begin{tabular}{|c|c|c|c|c|c|c|c|c|c|c|}
\hline \multicolumn{2}{|c|}{ Ranking by: } & \multirow[t]{2}{*}{ Corporation } & \multirow[t]{2}{*}{ Industry } & \multicolumn{2}{|c|}{ Assets } & \multicolumn{2}{|c|}{ Sales } & \multicolumn{2}{|c|}{ Employment } & \multirow[t]{2}{*}{ TNI\% } \\
\hline 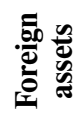 & $\bar{Z}$ & & & 泀 & 흉 & 氧 & 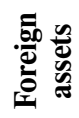 & ZZ & 芜 & \\
\hline 9 & 63 & LUKOIL & \begin{tabular}{|l|} 
Petroleum \\
Refining \\
and Related \\
Industries
\end{tabular} & 23.3 & 84 & 71.6 & 86.1 & 19.6 & 130 & 42.0 \\
\hline 39 & 55 & Evraz & \begin{tabular}{|l|} 
Metal \\
and metal \\
products
\end{tabular} & 9.4 & 17.6 & 8.7 & 13.4 & 24.3 & 110.2 & 46.7 \\
\hline 42 & 71 & Severstal & \begin{tabular}{|l|} 
Metal \\
and metal \\
products
\end{tabular} & 8.7 & 19.3 & 7.4 & 13.6 & 14.1 & 84.9 & 38.6 \\
\hline 50 & 81 & VimpelCom & $\begin{array}{l}\text { Telecom- } \\
\text { munications }\end{array}$ & 7.1 & 19.9 & 2.4 & 10.5 & 10 & 42 & 27.4 \\
\hline 53 & 96 & System & $\begin{array}{l}\text { Telecom- } \\
\text { munications }\end{array}$ & 6.2 & 44.1 & 3 & 28.1 & 18.6 & 135. & 12.8 \\
\hline 56 & 79 & Mechel & $\begin{array}{l}\text { Metal } \\
\text { and metal } \\
\text { products }\end{array}$ & 5.8 & 15.8 & 4.9 & 9.7 & 9.1 & 88.1 & 32.5 \\
\hline 70 & 74 & RUSAL & $\begin{array}{l}\text { Metal } \\
\text { and metal } \\
\text { products }\end{array}$ & 4.5 & 26.5 & 8.7 & 11 & 8.9 & 72.4 & 36.1 \\
\hline 71 & 73 & $\begin{array}{l}\text { Norilsk } \\
\text { Nickel }\end{array}$ & $\begin{array}{l}\text { Metal } \\
\text { and metal } \\
\text { products }\end{array}$ & 4.2 & 23.9 & 11.7 & 12.8 & 2.3 & 82.7 & 37.3 \\
\hline 83 & 91 & MTS & $\begin{array}{l}\text { Telecom- } \\
\text { munications }\end{array}$ & 3.1 & 14.5 & 1.9 & 11.3 & 6.4 & 39.9 & 18.1 \\
\hline 96 & 82 & TMK & \begin{tabular}{|l|} 
Metal \\
and metal \\
products
\end{tabular} & 2.4 & 6.9 & 2.1 & 5.6 & 4.9 & 48.9 & 27.4 \\
\hline
\end{tabular}

Source: UNCTAD, World Investment Report 2012. 
2011

\begin{tabular}{|c|c|c|c|c|c|c|c|c|c|c|}
\hline \multicolumn{2}{|c|}{ Ranking by: } & \multirow[t]{2}{*}{ Corporation } & \multirow[t]{2}{*}{ Industry } & \multicolumn{2}{|c|}{ Assets } & \multicolumn{2}{|c|}{ Sales } & \multicolumn{2}{|c|}{ Employment } & \multirow[t]{2}{*}{ TNI\% } \\
\hline 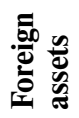 & $\bar{Z}$ & & & . & हैं & 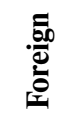 & 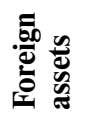 & $\underset{G}{Z}$ & हैं & \\
\hline 9 & 53 & VimpelCom & \begin{tabular}{|l|} 
Metal and \\
metal products
\end{tabular} & 29.8 & 54 & 11.3 & 20.3 & 34.5 & 66 & 54.4 \\
\hline 11 & 67 & LUKOIL & \begin{tabular}{|l|} 
Petroleum \\
Refining \\
and Related \\
Industries
\end{tabular} & 29.2 & 91.2 & 109 & 133.7 & 18.1 & 120.3 & 42.9 \\
\hline 28 & 85 & Gazprom & \begin{tabular}{|l|} 
Mining, \\
quarrying and \\
petroleum
\end{tabular} & 15.8 & 394.7 & 91.4 & 161.2 & 25.9 & 404.4 & 22.4 \\
\hline 55 & 65 & Evraz & \begin{tabular}{|l|} 
Metal and \\
metal products
\end{tabular} & 8.3 & 17 & 10 & 16.4 & 24.6 & 112 & 43.4 \\
\hline 57 & 84 & Severstal & \begin{tabular}{|l|} 
Metal and \\
metal products
\end{tabular} & 7.6 & 17.9 & 1.6 & 15.8 & 11.6 & 69.6 & 23.2 \\
\hline 65 & 80 & Mechel & \begin{tabular}{|l|} 
Metal and \\
metal products
\end{tabular} & 6.4 & 19.3 & 6.8 & 13 & 12 & 97 & 33.2 \\
\hline 74 & 95 & System & $\begin{array}{l}\text { Telecom- } \\
\text { munications }\end{array}$ & 5.2 & 43.9 & 2.5 & 33 & 19.7 & 143 & 11.1 \\
\hline 78 & 76 & RUSAL & $\begin{array}{l}\text { Metal and } \\
\text { metal products }\end{array}$ & 4.6 & 25.4 & 9.7 & 12.3 & 7.1 & 72 & 35.7 \\
\hline
\end{tabular}

Source: UNCTAD, World Investment Report 2013.

2012

\begin{tabular}{|c|c|c|c|c|c|c|c|c|c|c|}
\hline \multicolumn{2}{|c|}{ Ranking by: } & \multirow[t]{2}{*}{ Corporation } & \multirow[t]{2}{*}{ Industry } & \multicolumn{2}{|c|}{ Assets } & \multicolumn{2}{|c|}{ Sales } & \multicolumn{2}{|c|}{ Employment } & \multirow[t]{2}{*}{ TNI\% } \\
\hline 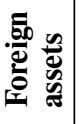 & Z & & & 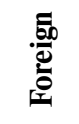 & 吾 & 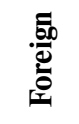 & 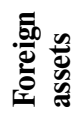 & Z & 惡 & \\
\hline 9 & 67 & LUKOIL & \begin{tabular}{|l|} 
Petroleum \\
Refining \\
and Related \\
Industries
\end{tabular} & 31.2 & 99 & 113.8 & 139.2 & 18.1 & 120.3 & 42.8 \\
\hline 17 & 85 & Gazprom & $\begin{array}{l}\text { Mining, } \\
\text { quarrying and } \\
\text { petroleum }\end{array}$ & 23.4 & 396.5 & 92 & 153.9 & 27.4 & 431.2 & 24.0 \\
\hline 76 & 86 & Severstal & $\begin{array}{l}\text { Metal } \\
\text { and metal } \\
\text { products }\end{array}$ & 6 & 15.7 & 2.3 & 14.1 & 11.6 & 67.3 & 23.9 \\
\hline 84 & 78 & Mechel & $\begin{array}{l}\text { Metal } \\
\text { and metal } \\
\text { products }\end{array}$ & 5.2 & 17.7 & 5.7 & 11.3 & 8.7 & 90.5 & 29.9 \\
\hline
\end{tabular}

Source: UNCTAD, World Investment Report 2014. 
2014

\begin{tabular}{|c|c|c|c|c|c|c|c|c|c|c|}
\hline \multicolumn{2}{|c|}{ Ranking by: } & \multirow[t]{2}{*}{ Corporation } & \multirow[t]{2}{*}{ Industry } & \multicolumn{2}{|c|}{ Assets } & \multicolumn{2}{|c|}{ Sales } & \multicolumn{2}{|c|}{ Employment } & \multirow[t]{2}{*}{ TNI\% } \\
\hline 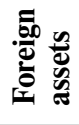 & $\bar{Z}$ & & & t. & हٓ⿱艹 & t. & 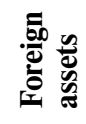 & Z & हैँ & \\
\hline 9 & 66 & LUKOIL & \begin{tabular}{|l|} 
Petroleum \\
Refining \\
and Related \\
Industries
\end{tabular} & 32.9 & 111.8 & 119.9 & 144.2 & 22.6 & 150 & 42.6 \\
\hline 41 & 85 & Gazprom & $\begin{array}{l}\text { Mining, } \\
\text { quarrying and } \\
\text { petroleum }\end{array}$ & 15.1 & 256.2 & 94.6 & 144.5 & 28.6 & 450 & 25.9 \\
\hline
\end{tabular}

Source: UNCTAD, World Investment Report 2016.

Analysis of table 3 shows a very unstable situation among Russian MNEs in the UNCTAD ranking of the largest non-financial transnational companies in the world, in developing countries, and in countries with transition eonomies. Moreover, over the last decade the list of Russian companies in the top 100 in the world ranking has constantly changed. Whereas in the first decade of this century the number consistently increased and reached eight in 2008 (the beginning of the global crisis), and 10 companies in 2010, in the second decade this figure steadily declined to eight companies in 2011, four in 2012 and two in 2014.

Table 4: Russian MNEs in the ranking of the top 100 non-financial MNEs from developing and transition economies, ranked by foreign assets

\begin{tabular}{|l|c|c|c|c|c|}
\hline & $\mathbf{2 0 0 8}$ & $\mathbf{2 0 1 0}$ & $\mathbf{2 0 1 1}$ & $\mathbf{2 0 1 2}$ & $\mathbf{2 0 1 4}$ \\
\hline LUKOIL & 8 & 9 & 11 & 9 & 9 \\
\hline Evraz & 23 & 39 & 55 & - & - \\
\hline Severstal & 32 & 42 & 57 & 76 & - \\
\hline System & 50 & 53 & 74 & - & - \\
\hline Norilsk Nickel & 64 & 71 & - & - & - \\
\hline VimpelCom & 74 & 50 & 9 & - & - \\
\hline Mechel & 81 & 56 & 65 & 84 & - \\
\hline TMK & 94 & 96 & - & - & - \\
\hline RUSAL & - & 70 & 78 & - & - \\
\hline MTS & - & 83 & - & - & - \\
\hline Gazprom & - & - & 28 & 17 & 41 \\
\hline
\end{tabular}

Source: UNCTAD, World Investment Report 2010-2016.

A detailed analysis of table 4 shows that almost all Russian companies in the ranking are characterized by a decrease in the level of capitalization and the value of foreign assets 
during the analyzed period. The only outlier on this list is LUKOIL, which consistently increases the overall level of its capitalization and volume of overseas expansion. At the same time, the majority of listed companies have a decline in foreign sales.

There are many reasons for this situation. The main one, in our opinion, is the low efficiency of foreign assets acquired by Russian companies as a result of mergers and acquisitions (M\&A) on foreign markets. Therefore some previously acquired assets of companies had to be divested due to the market downturn during the crisis, with obvious financial losses.

The second important reason is the absence in most Russian companies of adequate management experience and adaptation of practices to the business culture and traditions of countries in which the assets were acquired, which could significantly reduce the synergistic effect of the foreign expansion of companies.

Finally, the long crisis in the Russian economy which began in 2008 and led to a highly unstable ruble, with a more than halving of its value by the end of the researched period, have had a very marked impact on the decline in Russian companies' capitalization.

Thus, in recent years the number of Russian MNEs in the UNCTAD rating has been steadily declining (reached a minimum in 2014). Only LUKOIL has kept and even strengthened its position. Gazprom was included the ranking in 2011, but was unable to stay at the level reached in $2013 .^{3}$

In the following situation the widespread notion among international experts that MNEs rule a globalised world should be taken with caution, especially when applied to Russian companies. It turns out that everything in the modern global world is not so simple and straightforward. Even those Russian companies that will undoubtedly, in our opinion, belong to MNEs, in the conditions of tense competition, easily fall under the economic and political sanctions that have a direct impact on their business activity.

For example we can consider how the current political and economic sanctions against the Russian Federation, resulting from changes in the geopolitical situation and the conflict in Ukraine, have affected the activities of Russian companies.

Table 5: Sanctions against Russian companies undertaken by the US

(The sanctions which have directly affected the oil-and-gas sector

of the Russian economy and the Russian energy companies are bold italicized)

\begin{tabular}{|l|l|}
\hline $\begin{array}{c}\text { Dates of adoption } \\
\text { of resolutions }\end{array}$ & \multicolumn{1}{|c|}{ Impact } \\
\hline March 4, 2014 & Froze investment cooperation with Russia \\
\hline March 13, 2014 & $\begin{array}{l}\text { Announced trial sales of five million barrels of oil from the Strategic Petroleum } \\
\text { Reserve, similar to the sulfur exported from Russia. }\end{array}$ \\
\hline March 20, 2014 & Imposed sanctions against AB Russia \\
\hline April 11, 2014 & Imposed sanctions against Chernomorneftegaz \\
\hline
\end{tabular}

${ }^{3}$ Until 2011 Gazprom did not give official confirmation of data to international organizations, therefore UNCTAD did not include the Russian company in the official ranking. 


\begin{tabular}{|c|c|}
\hline $\begin{array}{l}\text { Dates of adoption } \\
\text { of resolutions }\end{array}$ & Impact \\
\hline April 28, 2014 & $\begin{array}{l}\text { Imposed sanctions against } 17 \text { Russian companies (AkvaNika, Avia Group, Avia Group } \\
\text { Nord, Zest, InvestCapitalBank, Sobinbank, Sahatrans, SMP Bank, Stroygazmontazh, } \\
\text { Stroytransgaz, Stroytransgaz-M, Stroytransgaz Holding, Abros, TRANSOIL, Volga } \\
\text { Group) }\end{array}$ \\
\hline May 7, 2014 & $\begin{array}{l}\text { Excluded Russia from the trade program allowing transition economies to import } \\
\text { duty-free to the US certain types of goods }\end{array}$ \\
\hline June 18, 2014 & $\begin{array}{l}\text { Toughened the export regime for five Russian entities: Fryazino Branch of the } \\
\text { Institute of Radio Engineering and Electronics, Russian Academy of Sciences, } \\
\text { Voentelekom, Business Security Academy, Nasosy Ampika, and Nuklin }\end{array}$ \\
\hline July 16, 2014 & $\begin{array}{l}\text { Introduced the first sanctions against key sectors of the Russian economy. Under the } \\
\text { sanctions are Rosneft, Novatek, state Vnesheconombank and Gazprombank. Against } \\
\text { the enterprises of the Russian military-industrial complex: Almaz-Antey, Izhmash, } \\
\text { Kalashnikov, Basalt, Uralvagonzavod and Instrument Design Bureau, NPO } \\
\text { Mashinostroyenia, KRET, and Sozvezdie }\end{array}$ \\
\hline July 29, 2014 & $\begin{array}{l}\text { Introduced sanctions against BM, VTB and Rosselkhozbank. US citizens and } \\
\text { companies are prohibited from acquiring debts of these banks or related entities, as } \\
\text { well as their property for a period exceeding } 90 \text { days }\end{array}$ \\
\hline August 6, 2014 & $\begin{array}{l}\text { Forbidden to supply to Russia equipment for underground mining (over } 152 \text { meters), } \\
\text { the development of the Arctic shelf and shale oil and gas reserves, the supply of non- } \\
\text { conventional energy production technologies: oil rigs, parts for horizontal drilling, subsea } \\
\text { equipment, marine equipment to operate in the Arctic, software for hydraulic fracturing, } \\
\text { remotely operated underwater vehicles, high-pressure pumps. Introduced a mandatory } \\
\text { inspection of the final recipient of unconventional energy production technologies with the } \\
\text { possibility of refusal in licensing }\end{array}$ \\
\hline August 26, 2014 & $\begin{array}{l}\text { Sanctions against Russia forced ExxonMobil to cancel } 9 \text { of } 10 \text { joint projects with Rosneft, } \\
\text { including exploration and potential production in Black Sea, in the Arctic and in Western } \\
\text { Siberia. The only current ExxonMobil project in Russia is Sakhalin-1 }\end{array}$ \\
\hline September 2, 2014 & $\begin{array}{l}\text { Imposed sanctions against: } \\
\text { 1) Gazprom, Lukoil, Transneft, Gazprom Neft, Surgutneftegas, Novatek, Rosneft. } \\
\text { American companies are prohibited from supplying them with products and technologies } \\
\text { required for the development of oil fields in deep water and the Arctic shelf, and in shale } \\
\text { formations. Corporations «Gazpromneft» and «Transneft» are also forbidden to take } \\
\text { loans and to place securities on the US market for more than } 90 \text { days. These measures are } \\
\text { intended to prevent the supply of technology and equipment to Russian companies, even } \\
\text { through intermediaries. } \\
\text { 2) Sberbank, BM, Gazprombank, Rosselkhozbank, Vnesheconombank, VTB, } \\
\text { Novatek and Rosneft. American citizens and companies are prohibited from buying bonds } \\
\text { of these banks and corporations with maturities of over } 30 \text { days, and from providing them } \\
\text { with loans. } \\
\text { 3) Enterprises of the military-industrial complex: the corporation Rostec, } \\
\text { Almaz-Antey, Dolgoprudnenskoe nauchno-proizvodstvennoe predprijatie, } \\
\text { Mashinostroitelnyj zavod named after Kalinin, Mytishhinskij mashinostroitelnyj } \\
\text { zavod, Nauchno-issledovatelskij institut priborostroenija named after Tikhomirov }\end{array}$ \\
\hline August 10, 2015 & $\begin{array}{l}\text { Expand sanctions against Russia. The sanctions list for the first time included a specific } \\
\text { deposit, namely South Kirinskoye condensate on the Okhotsk Sea shelf (owned by } \\
\text { Gazprom and one of the Sakhalin-3 project blocks). Now, equipment of US origin cannot } \\
\text { be supplied for the development of this deposit. This measure threatens to disrupt the } \\
\text { plans of Gazprom for the development of the South Kirinskoye deposit, as well as projects } \\
\text { associated with it; cooperation between Gazprom and Shell is particularly under threat }\end{array}$ \\
\hline
\end{tabular}

Source: compiled by the authors. 
The sanctions, which were imposed by the US and supported and strengthened by European Union countries, ${ }^{4}$ have seriously limited the business relations of Russian companies with key foreign partners, leading to a fall in investment and the cancelation of many large projects, with a noticeable impact on the financial performance of the companies. ${ }^{5}$ The sanctions have affected $90 \%$ of Russian oil companies and almost all gas companies (table 5 sections in bold italics). American companies are prohibited from supplying them with products and technology required for the development of oil fields in deep water, in the Arctic shelf and in shale formations. Deliveries are forbidden even through intermediaries. As a result, many large-scale projects were canceled. ${ }^{6}$

The current situation has also had a direct negative impact on financial the performance of oil and gas companies. An additional factor contributing to the sanctions is the steady fall of oil price, which was directly reflected in companies' income. Thus, the net profit of Lukoil for the first half of 2014 dropped by $12 \%$ to $\$ 4.1$ billion. $^{7}$ The net profit of Gazprom fell more than $20 \%$, from 593.41 billion to 465.23 billion rubles. ${ }^{8}$

The collapse of the ruble has also brought its own significant adjustments to the financial performance of the companies, as some of them make payments for exports in rubles with certain business partners.

So Russian oil and gas companies have come under double pressure. On the one hand, there are the political and economic sanctions imposed by developed countries of the West and on the other, the economic crisis resulted in a drop in demand, a significant reduction in investment programs, and a more than $50 \%$ devaluation of the ruble.

As a result, the relatively weak transnationalization of the largest Russian companies in general (in particular in the energy sector) and also the low level of their involvement in the tools and mechanisms for the creation of global corporations, do not allow them to easily overcome the effects of economic and political cataclysms. The main losses were in two key business areas: (a) the possibility of finding sources of financing, independent from the imposed restrictions, for corporations' long-term investments, and (b) the replacement of advanced modern technologies owned by the largest companies in Western countries (cooperation with which was canceled under the existing sanctions) with their own developments or technology affiliated with Russian companies, foreign branches or

${ }^{4}$ The purpose of this article is not a structuring of the US and the EU sanctions and ascertaining of the sequence of their application against Russia. In this regard we will be limited by the given example as an illustration of the impact of US sanctions on the activities of Russian energy companies.

${ }^{5}$ The fall of capitalization of Russian companies on MICEX is estimated at $\$ 62.5$ billion.

${ }^{6}$ Gazprom Neft has suspended cooperation with Shell on the development of shale oil in the "Khanty-Mansiysk oil union." Another joint venture of Gazprom Neft and Shell, Salym Petroleum Development (SPD), is also experiencing difficulties because of the sanctions [Oil \& Gas Eurasia, 2014]. 2014].

ExxonMobil has canceled almost all joint projects with Rosneft [Oil \& Gas Eurasia,

${ }^{7}$ Lukoil financial report, 2014. Available at: http://www.lukoil.ru/new/finreports/2014 (accessed 20 August 2016) (in Russian).

${ }^{8}$ Gazprom financial report, 2014. Available at: http://www.gazprom.ru/f/posts/05/298369/ gazprom-ifrs-2q2014-ru.pdf (accessed 20 August 2016) (in Russian). 
subsidiaries. This has led to a freezing of large-scale projects and a search for options to replace technology solutions that are traditionally used by leading global companies.

The illusion that MNEs in the modern world are in control of decisions in the implementation of their business projects is gradually collapsing. The research conducted by the authors is an example of this. Even for companies that are in the world elite (top 500), when it comes to political restrictions and economic sanctions, they are not able to make their own decisions in the implementation of full-scale projects which have mutual economic interest. This statement equally applies both to Russian and foreign MNEs. The examples of violent political restrictions on the activities of ExxonMobil, Shell, SPD and other companies of developed countries on the Russian market clearly prove this.

Modern practice destroys the illusion of the unlimited possibilities of solving any problems that arise in global markets, in the conditions of the general globalization of the world economy. The concepts of global financial and industrial markets in the conditions of increasing political pressure upon the activities of business units and first of all MNEs, are put under question.

In this situation, Russian MNEs have borne significant losses due to their hope that access to the world elite would allow them easily build difficult technological chains in global markets to solve problems, which failed suddenly. At the same time a hope of active participation in global schemes has led to a marked reduction in R\&D spending (research and development of Russian terminology) by Russian companies in recent years, a reluctance of the largest Russian companies to invest significant resources in construction work, and the disappearance of design institutes and departments in whole sectors of the economy. The inability to quickly train experts also has a negative effect on the speed of overcoming problems.

The euphoria of opportunities to take advantage of globalization in the world economy is replaced by a sober feeling that recovery of full technological and financial chains for large-scale projects is possible only with an expansion of business contacts with companies of developing countries and a recovery of national institutes of technology development through the resources of the private sector and Russian state support. Resolving these issues will take a long time and a significant financial effort from the largest Russian companies. 


\section{References}

Caves R. (2007) Multinational Enterprise and Economic Analysis. Cambridge University Press.

Forbes (2015) 200 krupnejshih kompanij Rossii [200 Largest Russian Companies]. Available at: http://www.forbes.ru/forbes/issue/2015-10/300529-200-krupneishikh-kompaniirossii (accessed 10 September 2016). (in Russian)

Gribova S.N. (2005) Globalizacija i regionalizacija determinanty mirovogo jekonomicheskogo razvitija [Globalization and Regionalization of Determinants of World Economic Development]. Jekonomicheskij zhurnal, no 9. Available at: http://cyberleninka. $\mathrm{ru} /$ article/n/globalizatsiya-i-regionalizatsiya-determinanty-mirovogo-ekonomicheskogorazvitiya (accessed 11 September 2016). (in Russian)

Hill Ch. (2013) Mezhdunarodnyj biznes [International Business]. Saint-Petersburg: Piter. (in Russian)

Jeskindarov M.A., Beljaeva I.Ju., Ploticyna L.A. (2010) Sovremennye korporativnye strategii i tehnologii v Rossii [Modern Corporate Ctrategy and Technology in Russia]: sb. nauch. st. Vol. 5. Part 1. Moscow: Finansovaja akademija pri Pravitel'stve RF. (in Russian)

Nikitina T.A. (2009) Vlijanie koncentracii i centralizacii kapitala na global'nuju i nacional'nuju jekonomiki [Influence of Concentration and Centralization of Capital in the Global and National Economy]. Kiev: Kievskij nacional'nyj universitet imeni Tarasa Shevchenko. (in Russian)

OECD (2011) Guidelines for Multinational Enterprises. Available at: http://www.oecd.org/ daf/inv/mne/48004323.pdf (accessed 01 November 2016).

Oil \& Gas Eurasia (2014) Bazhenovskaja svita popadet pod zapadnye sankcii [Bazhenov formation Comes under Western Sanctions], 7 October. Available at: https://www.oilandgaseurasia.com/ru/news/bazhenovskaja-svita-popadet-pod-zapadnye-sankcii (accessed 14 January 2016). (in Russian)

PanibratovA.Ju.(2006) Marketingovye modeliimetody proniknovenija mnogonacional'nyh kompanij na rossijskie rynki [Marketing Models and Methods of Penetration of Multinational Companies in Russian Market] (Thesis). Moscow: GUU. (in Russian)

Pozdnjakov A.I. (2011) Globalizacija i ee vlijanie na mezhdunarodnuju bezopasnost' i voennuju politiku Rossijskoj Federacii [Globalization and its Impact on International Security and Military Policy of Russian Federation]. Prostranstvo i Vremja, no 2. Available at: 
http://cyberleninka.ru/article/n/globalizatsiya-i-ee-vliyanie-na-mezhdunarodnuyu-bezopasnost-i-voennuyu-politiku-rossiyskoy-federatsii (accessed 11 September 2016).

$R B K$ (2014) Exxonmobil zamorozila 9 sovmestnyh proektov s "Rosneft'ju" [Exxonmobil Froze 9 Joint Projects with Rosneft]. Available at: https://www.oilandgaseurasia.com/ru/ news/exxonmobil-zamorozila-9-sovmestnyh-s-«rosneft'ju»-proektov (accessed 14 January 2016). (in Russian)

$R B K$ (2015) RBK 500. Available at: http://www.rbc.ru/rbc500/ (accessed 01 November 2016). (in Russian)

Smitienko B.M. (2009) Aktual'nye problemy jeffektivnogo vkljuchenija Rossii v sovremennye mirohozjajstvennye svjazi [The current issues of effective integration of Russia in the modern world economy]. Finansovo-nalogovye, bankovskie $i$ valjutnye aspekty integracii Rossii v mirovuju jekonomiku: nauch. al'manah fundamental'nyh i prikladnyh issledovanij (ed. L.N. Krasavina). Moscow: Finansovaja akademija pri Pravitel'stve RF. (in Russian)

UNCTAD (2009) The United Nations Code of Conduct on Transnational Corporations. Available at: http://unctad.org/en/Docs/wir2009_en.pdf (accessed 01 November 2016).

UNCTAD (2015) The United Nations Code of Conduct on Transnational Corporations. Available at: http://unctad.org/sections/dite/iia/docs/Compendium/en/13\%20volume\% 201.pdf (accessed 01 November 2016).

UNCTAD (2016) Transnational corporations. Available at: http://unctad.org/en/Pages/ DIAE/Transnational-corporations-(TNC).aspx (accessed 01 November 2016). 